\title{
State of soil enzymatic activity in relationship to some chemical properties of Brunic Arenosols
}

\author{
Jarosław Lasota, Ewa Błońska, Wojciech Piaszczyk* \\ Department of Ecology and Silviculture, Faculty of Forestry, University of Agriculture in Krakow, 29 Listopada 46 Str., 31-425 Kraków, Poland \\ * dr inż. W. Piaszczyk, wojciech.piaszczyk@urk.edu.pl, ORCID iD: https://orcid.org/0000-0002-4099-3823
}

Received: 23.02 .2021

Accepted: 30.07.2021

Associated editor: J. Wyszkowska

\section{Keywords}

Acidity
Carbon content
Forest soils
Dehydrogenases
Protease
Urease

\begin{abstract}
Brunic Arenosols are one of the most common soil types in lowland forests. The aim of this study was to determine the enzymatic activity of trophically diverse forest Brunic Arenosols. In this study, an attempt was made to determine the relationship between enzymatic activity and some chemical properties of Brunic Arenosols. It has been presented how the activity of dehydrogenases, urease and protease changes deep into the profile of Brunic Arenosols. Sample plots were located in central Poland, in the Przedbórz forest district. 23 sample plots have been selected for the research. The research concerned Albic Brunic Arenosols (9 plots), Haplic Brunic Arenosols (7 plots) and Cambic Brunic Arenosols (7 plots). At each sample plot a detailed description of soil profile has been carried out, samples have been taken from each genetic horizon in order to mark of soil properties and enzyme activity. The analyses carried out confirmed the relationship of enzymatic activity with the content of C, N, pH and the texture in the studied soils. Regardless of the type of enzyme, a decrease in activity has been observed in the depth of the profile which is related to the availability of carbon substrates necessary for enzymatic reactions. Dehydrogenases activity reflects the trophic conditions of Brunic Arenosols better than other tested enzymes. The highest dehydrogenases activity was recorded in Cambic Brunic Arenosols. For protease and urease activities, no clear differences were recorded between Brunic Arenosols subtypes. Extracellular enzyme activities were most strongly associated with organic horizons regardless of Brunic Arenosols subtype.
\end{abstract}

\section{Introduction}

Brunic Arenosols are among the most common soil types in lowland forests. Poor agricultural properties of Brunic Arenosols result from the nature of parent material of these soils, which are permeable, usually deep and leached sandy formations of fluvioglacial or glacial origin, less frequently of eolian origin. A diagnostic feature of the Brunic Arenosols is the occurrence of a sideric horizon under the humus accumulation horizon, characterized by a rusty color with varying saturation. The color is a result of intensive weathering and the formation of immobile bonds of semi-oxides (mostly iron and aluminum) with humus acids. According to the Classification of Forest Soils in Poland (2000), there are three subtypes of Brunic Arenosols: Albic Brunic Arenosols, Haplic Brunic Arenosols and Cambic Brunic Arenosols. Albic Brunic Arenosols are associated with poor forest habitats, coniferous forest sites or mixed coniferous forest sites. Haplic Brunic Arenosols cover mixed coniferous forest sites or mixed broadleaf forest sites. Cambic Brunic Arenosols are associated with the richest habitats (mixed broadleaf forest sites or broadleaf forest sites) (Lasota and Błońska, 2013).
Soil enzymes play a significant role in the decomposition of soil organic matter and regulate carbon accumulation and nutrient reserves (Burns and Dick, 2002; Sinsabaugh et al., 2008; Baldrian, 2014). Enzyme production requires microbial energy inputs in the form of $\mathrm{C}$ and nutrients (Schimel and Weintraub, 2003; Hernández and Hobbie, 2010). A better understanding of the relationship between chemical properties of soils and their enzymatic activity leads to a better understanding of the dynamics of biogeochemical processes occurring in soils (Allison et al., 2010; Cusack et al., 2011). Numerous factors that regulate enzymatic activity include the quantity and quality of plant debris and root secretions supplied to the soil (Hernández and Hobbie, 2010). The most important way in which individual trees affect soil properties is through the organic matter they supply to the soil. Monitoring by means of studying microbiological and biochemical properties of soils are successfully applied (Friedlová, 2010; Błońska et al., 2020b). Biochemical properties react to changes quickly, they are directly related to the amount and activity level of soils microbiota (Błońska et al., 2021). Soil enzymatic activities are sensitive bio-indicators of any natural and anthropogenic disturbance (Kumar et al., 2013). The activ- 
ity of soil enzymes is one of the approved parameters used for the evaluation of soil quality (Lipińska et al., 2013). Lasota and Błońska (2018) confirmed that contamination with PAHs modified the physical properties of forest soils and had a negative impact on enzyme activity in soil. Dehydrogenases are the most important soil enzymes and are frequently used in determining soil quality (Margesin et al., 2000). Urease activity is determined by various factors, including the type of contaminant, $\mathrm{pH}$, and organic carbon content (Baran et al., 2004; Zhan et al., 2010). Proteases are enzymes involved in the first stage of nitrogen release, in the process of its mineralization (Sardans et al., 2008).

So far, few studies have been conducted on the biochemical activity of forest Brunic Arenosols. The objective of this study was to determine the enzymatic activity of trophically diverse forest Brunic Arenosols. In this study, an attempt was made to determine the relationship between enzymatic activity and chemical properties of Brunic Arenosols. The research studied the way in which the activity of dehydrogenases, urease and protease changes deep into the profile of different subtypes of Brunic Arenosols.

\section{Materials and methods}

\subsection{Study area and experimental design}

Sample plots were located in central Poland, in the Przedbórz forest district $\left(51^{\circ} 05^{\prime} \mathrm{N}, 19^{\circ} 52^{\prime} \mathrm{E}\right)$. The test area was dominated by stands pine (P. sylvestris), sessile oak (Quercus petraea) and mixed-species stand (pine (P. sylvestris) plus sessile oak (Quercus petraea)). The local soils are derived from sandy fluvioglacial deposits. 23 sample plots have been selected for the research. The research concerned Albic Brunic Arenosols (9 plots), Haplic Brunic Arenosols (7 plots) and Cambic Brunic Arenosols (7 plots). At each sample plot a detailed description of soil profile has been carried out, samples were taken from each genetic horizon in order to perform the basic markings of the soil properties. The samples for laboratory analysis were collected in September 2008. For the determination of enzymatic activity, one part of fresh samples with natural moisture were passed through a sieve $(\varnothing 2 \mathrm{~mm})$ and stored at $4^{\circ} \mathrm{C}$ before the analysis. For an analysis of physical and chemical properties, samples were airdried at room temperature condition and then sieved.

\subsection{Laboratory analysis}

The texture was determined using laser diffraction (Analysette 22, Fritsch, Idar-Oberstein, Germany). The soil pH was determined in $\mathrm{H}_{2} \mathrm{O}$ and $\mathrm{KCl}$ using the potentiometric method. $\mathrm{C}$ and $\mathrm{N}$ were measured using an elemental analyzer (LECO CNS TrueMac Analyzer Leco, St. Joseph, MI, USA). The cation concentrations $\left(\mathrm{Ca}^{2+}, \mathrm{Mg}^{2+}, \mathrm{K}^{+}, \mathrm{Na}^{+}\right)$were determined after extraction in $1 \mathrm{M}$ ammonium acetate by inductively-coupled plasma analysis (ICP-OES Thermo iCAP 6500 DUO, Thermo Fisher Scientific, Cambridge, UK).

Dehydrogenases activity (DH) was determined using Lenhard's method according to the Casida procedure (Alef and Nan- nipieri, 1995). Urease activity (UR) was determined according to Tabatabai and Bremner (1972) using a water-urea solution as a substrate. Protease activity (PR) was marked with Hoffman and Teicher method (Haziev, 1976). In the soil samples the activity of dehydrogenase (EC 1.1.1.1), urease (EC 3.5.1.5) and protease (EC 3.4.21) were determined in three repetitions.

\subsection{Statistical analysis}

The Spearman correlation coefficients for the soil characteristics were calculated. The distribution was checked for normality. To assess differences between means for the properties of the soils we used the Kruskal-Wallis test. On the basis of Ward's method (Everrit 1980), agglomeration of the soil horizon differing in enzyme activity was conducted. Using the principal components analysis (PCA) method, we evaluated the relationships between soil properties. All statistical analyses were performed with Statistica 13 software (2012).

\section{Results}

The enzymatic activity of Albic Brunic Arenosols varied deep into the profile (Table 1). Statistically significantly higher UR, PR and $\mathrm{DH}$ activities were noted for the surface horizons of the studied soils, i.e., the Ofh and AEes horizons. At the same time, the surface horizons of Albic Brunic Arenosols were characterized by significantly higher $\mathrm{C}$ and $\mathrm{N}$ contents. The average $\mathrm{C}$ content in the Ofh horizons was $233.6 \mathrm{~g} \mathrm{~kg}^{-1}$ and the $\mathrm{N}$ content was $8.5 \mathrm{~g} \mathrm{~kg}^{-1}$. Ofh and AEes horizons showed significantly lower $\mathrm{pH}$ compared with the deeper ones. In case of Albic Brunic Arenosols, the highest content of base cations was recorded in the Ofh horizon. Albic Brunic Arenosols were characterized by the highest sand fraction content ranging from 92 to 94\% (Table 1). In case of Haplic Brunic Arenosols, the activity of tested enzymes was statistically significantly higher in the Ofh horizon and decreased significantly deeper into the profile (Table 2). Significantly higher $\mathrm{C}$ and $\mathrm{N}$ contents were recorded in the surface horizons, i.e., Ofh and $\mathrm{A} / \mathrm{ABv}$. The mean $C$ content in Ofh horizon was $142.3 \mathrm{~g}_{\mathrm{kg}} \mathrm{kg}^{-1}$ and nitrogen content was $5.7 \mathrm{~g}_{\mathrm{kg}}{ }^{-1}$. The surface horizons were characterized by significantly lower $\mathrm{pH}$ as compared with the deeper horizons. The Ofh horizon of Haplic Brunic Arenosols was characterized by a significantly higher content of base cations compared to the mineral horizons. The average sand fraction content of Haplic Brunic Arenosols ranged from 90 to 93\% (Table 2). In the case of Cambic Brunic Arenosols, statistically significantly higher UR, PR and DH activities were recorded in the Oh/A horizon (Table 3). At the same time, this horizon has been characterized by higher $\mathrm{C}$ and $\mathrm{N}$ content and significantly lower $\mathrm{pH}$. Significantly higher content of base cations was noted in the Oh/A horizon of Cambic Brunic Arenosols. In the Cambic Brunic Arenosols profile, the average sand content ranged from 81 to $85 \%$ (Table 3).

The studied Brunic Arenosols subtypes did not differ greatly in protease and urease activity (Fig. 1, Table 1-3). No statistically important differences were recorded for PR and UR activities in the surface horizons of the studied soils. More pronounced differences were recorded for dehydrogenases activity. Dehydroge- 
Table 1

Enzyme activity and physicochemical properties of Albic Brunic Arenosols

\begin{tabular}{|c|c|c|c|c|c|c|c|c|c|c|c|c|c|c|c|}
\hline & UR & $\mathrm{PR}$ & $\mathrm{DH}$ & $\mathrm{C}$ & $\mathrm{N}$ & $\mathrm{C} / \mathrm{N}$ & $\mathrm{pH} \mathrm{H}_{2} \mathrm{O}$ & $\mathrm{pH} \mathrm{KCl}$ & $\mathrm{Ca}$ & $\mathrm{K}$ & $\mathrm{Mg}$ & $\mathrm{Na}$ & sand & silt & clay \\
\hline \multirow[t]{2}{*}{ Ofh } & $9.80 \pm$ & $284.04 \pm$ & $11.68 \pm$ & $233.6 \pm$ & $8.5 \pm$ & $27.0 \pm$ & $3.77 \pm$ & $2.96 \pm$ & $87.93 \pm$ & $1.16 \pm$ & $6.82 \pm$ & $1.81 \pm$ & - & - & - \\
\hline & $3.77^{a}$ & $38.16^{a}$ & $4.51^{\mathrm{a}}$ & $111.6^{\mathrm{a}}$ & $3.5^{\mathrm{a}}$ & $3.7^{\mathrm{a}}$ & $0.21^{\mathrm{b}}$ & $0.22^{\mathrm{b}}$ & $29.35^{a}$ & $6.29^{a}$ & $2.90^{\mathrm{a}}$ & $0.45^{\mathrm{a}}$ & & & \\
\hline \multirow[t]{2}{*}{ AEes } & $3.97 \pm$ & $141.41 \pm$ & $3.67 \pm$ & $21.4 \pm$ & $0.8 \pm$ & $23.8 \pm$ & $3.89 \pm$ & $3.18 \pm$ & $6.66 \pm$ & $1.61 \pm$ & $0.58 \pm$ & $0.70 \pm$ & $92 \pm 2$ & $5 \pm 2$ & $2 \pm 1$ \\
\hline & $1.51^{\mathrm{a}}$ & $26.33^{a}$ & $2.63^{a}$ & $6.5^{\mathrm{a}}$ & $0.2^{\mathrm{a}}$ & $3.8^{\mathrm{a}}$ & $0.18^{b}$ & $0.18^{b}$ & $2.99^{\mathrm{ab}}$ & $0.68^{a}$ & $0.19^{a b}$ & $0.20^{\mathrm{b}}$ & & & \\
\hline \multirow[t]{2}{*}{ BvBhfe } & $1.57 \pm$ & $67.54 \pm$ & $0.44 \pm$ & $11.6 \pm$ & $0.5 \pm$ & $20.1 \pm$ & $4.45 \pm$ & $3.91 \pm$ & $3.64 \pm$ & $0.83 \pm$ & $0.39 \pm$ & $0.61 \pm$ & $94 \pm 2$ & $5 \pm 2$ & $1 \pm 1$ \\
\hline & $0.60^{\mathrm{b}}$ & $23.81^{\mathrm{b}}$ & $0.32^{\mathrm{b}}$ & $7.2^{\mathrm{b}}$ & $0.1^{\mathrm{b}}$ & $10.3^{\mathrm{ab}}$ & $0.23^{\mathrm{a}}$ & $0.29^{\mathrm{a}}$ & $1.28^{\mathrm{b}}$ & $0.26^{\mathrm{b}}$ & $0.14^{\mathrm{b}}$ & $0.25^{\mathrm{b}}$ & & & \\
\hline \multirow[t]{2}{*}{$\mathrm{Bv}$} & $0.81 \pm$ & $43.17 \pm$ & $0.08 \pm$ & $5.7 \pm$ & $0.4 \pm$ & $14.8 \pm$ & $4.61 \pm$ & $4.22 \pm$ & $2.96 \pm$ & $0.58 \pm$ & $0.31 \pm$ & $0.71 \pm$ & $94 \pm 2$ & $5 \pm 2$ & $1 \pm 2$ \\
\hline & $0.66^{\mathrm{b}}$ & $30.30^{\mathrm{b}}$ & $0.06^{b}$ & $3.2^{\mathrm{b}}$ & $0.2^{\mathrm{b}}$ & $5.0^{\mathrm{b}}$ & $0.11^{\mathrm{a}}$ & $0.14^{\mathrm{a}}$ & $0.95^{b}$ & $0.10^{\mathrm{b}}$ & $0.10^{\mathrm{b}}$ & $0.35^{\mathrm{b}}$ & & & \\
\hline
\end{tabular}

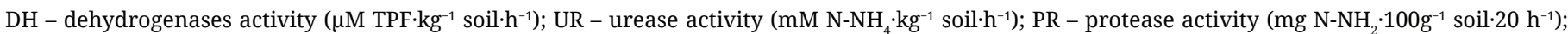
$\mathrm{C}$ and $\mathrm{N}$ content $\left(\mathrm{g} \cdot \mathrm{kg}^{-1}\right)$; $\mathrm{Ca}, \mathrm{K}, \mathrm{Mg}$ and $\mathrm{Na}\left(\mathrm{cmol}(+) \cdot \mathrm{kg}^{-1}\right)$; sand, silt and clay content in \%; small letters in the upper index of the mean values mean significant differences between horizons

Table 2

Enzyme activity and physicochemical properties of Haplic Brunic Arenosols

\begin{tabular}{|c|c|c|c|c|c|c|c|c|c|c|c|c|c|c|c|}
\hline & UR & PR & $\mathrm{DH}$ & C & $\mathrm{N}$ & $\mathrm{C} / \mathrm{N}$ & $\mathrm{pH} \mathrm{H}_{2} \mathrm{O}$ & $\mathrm{pH} \mathrm{KCl}$ & $\mathrm{Ca}$ & K & $\mathrm{Mg}$ & $\mathrm{Na}$ & sand & silt & clay \\
\hline \multirow[t]{2}{*}{ Ofh } & $10.96 \pm$ & $238.64 \pm$ & $20.60 \pm$ & $142.3 \pm$ & $5.7 \pm$ & $24.3 \pm$ & $4.05 \pm$ & $3.21 \pm$ & $61.37 \pm$ & $13.54 \pm$ & $7.43 \pm$ & $1.41 \pm$ & - & - & - \\
\hline & $3.98^{\mathrm{a}}$ & $66.09^{\mathrm{a}}$ & $9.72^{\mathrm{a}}$ & $54.3^{\mathrm{a}}$ & $1.5^{\mathrm{a}}$ & $6.0^{\mathrm{a}}$ & $0.16^{b}$ & $0.26^{b}$ & $21.18^{\mathrm{a}}$ & $6.33^{\mathrm{a}}$ & $3.35^{\mathrm{a}}$ & $0.51^{\mathrm{a}}$ & & & \\
\hline \multirow[t]{2}{*}{$\mathrm{A} / \mathrm{ABv}$} & $3.25 \pm$ & $117.35 \pm$ & $2.32 \pm$ & $22.2 \pm$ & $1.1 \pm$ & $21.0 \pm$ & $4.34 \pm$ & $3.58 \pm$ & $9.95 \pm$ & $2.06 \pm$ & $11.11 \pm$ & $0.75 \pm$ & $90 \pm 3$ & $7 \pm 4$ & $2 \pm 1$ \\
\hline & $1.03^{\mathrm{ab}}$ & $50.98^{\mathrm{ab}}$ & $2.29^{\mathrm{ab}}$ & $5.6^{\mathrm{a}}$ & $0.2^{\mathrm{a}}$ & $1.6^{\mathrm{ab}}$ & $0.28^{b}$ & $0.25^{b}$ & $6.27^{\mathrm{ab}}$ & $1.65^{\mathrm{ab}}$ & $0.90^{\mathrm{ab}}$ & $0.22^{\mathrm{ab}}$ & & & \\
\hline \multirow[t]{2}{*}{$\mathrm{ABv} / \mathrm{Bv}$} & $1.44 \pm$ & $61.09 \pm$ & $0.26 \pm$ & $9.0 \pm$ & $0.5 \pm$ & $16.0 \pm$ & $4.75 \pm$ & $4.14 \pm$ & $4.22 \pm$ & $0.78 \pm$ & $0.41 \pm$ & $0.53 \pm$ & $92 \pm 3$ & $7 \pm 2$ & $1 \pm 1$ \\
\hline & $0.56^{\mathrm{b}}$ & $22.51^{\mathrm{b}}$ & $0.20^{\mathrm{b}}$ & $3.7^{b}$ & $0.1^{\mathrm{b}}$ & $3.9^{b}$ & $0.19^{\mathrm{a}}$ & $0.11^{\mathrm{a}}$ & $0.57^{\mathrm{b}}$ & $0.13^{\mathrm{b}}$ & $0.08^{b}$ & $0.13^{\mathrm{b}}$ & & & \\
\hline \multirow[t]{2}{*}{$\mathrm{BvC}$} & $0.78 \pm$ & $72.03 \pm$ & $0.27 \pm$ & $2.6 \pm$ & $0.2 \pm$ & $11.7 \pm$ & $4.82 \pm$ & $4.28 \pm$ & $3.80 \pm$ & $0.86 \pm$ & $0.43 \pm$ & $0.45 \pm$ & $93 \pm 3$ & $6 \pm 3$ & $1 \pm 1$ \\
\hline & $0.32^{\mathrm{b}}$ & $64.02^{\mathrm{b}}$ & $0.22^{\mathrm{b}}$ & $1.2^{\mathrm{b}}$ & $0.1^{\mathrm{b}}$ & $3.5^{\mathrm{b}}$ & $0.15^{a}$ & $0.11^{\mathrm{a}}$ & $2.58^{\mathrm{b}}$ & $0.23^{b}$ & $0.32^{\mathrm{b}}$ & $0.09^{b}$ & & & \\
\hline
\end{tabular}

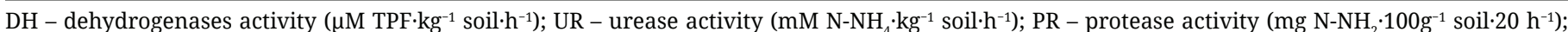
$\mathrm{C}$ and $\mathrm{N}$ content $\left(\mathrm{g} \cdot \mathrm{kg}^{-1}\right)$; $\mathrm{Ca}, \mathrm{K}, \mathrm{Mg}$ and $\mathrm{Na}\left(\mathrm{cmol}(+) \cdot \mathrm{kg}^{-1}\right)$; sand, silt and clay content in \%; small letters in the upper index of the mean values mean significant differences between horizons

Table 3

Enzyme activity and physicochemical properties of Cambic Brunic Arenosols

\begin{tabular}{|c|c|c|c|c|c|c|c|c|c|c|c|c|c|c|c|}
\hline & UR & $\mathrm{PR}$ & $\mathrm{DH}$ & $\mathrm{C}$ & $\mathrm{N}$ & $\mathrm{C} / \mathrm{N}$ & $\mathrm{pH} \mathrm{H}_{2} \mathrm{O}$ & $\mathrm{pH} \mathrm{KCl}$ & $\mathrm{Ca}$ & $\mathrm{K}$ & $\mathrm{Mg}$ & $\mathrm{Na}$ & sand & silt & clay \\
\hline \multirow[t]{2}{*}{$\mathrm{Oh} / \mathrm{A}$} & $11.20 \pm$ & $232.65 \pm$ & $22.66 \pm$ & $67.2 \pm$ & $3.7 \pm$ & $16.9 \pm$ & $3.99 \pm$ & $3.22 \pm$ & $36.55 \pm$ & $10.87 \pm$ & $4.53 \pm$ & $1.01 \pm$ & - & - & - \\
\hline & $1.40^{\mathrm{a}}$ & $63.59^{a}$ & $4.93^{\mathrm{a}}$ & $50.5^{\mathrm{a}}$ & $2.5^{\mathrm{a}}$ & $2.9^{b}$ & $0.19^{b}$ & $0.15^{\mathrm{b}}$ & $32.08^{a}$ & $9.99^{\mathrm{a}}$ & $4.03^{\mathrm{a}}$ & $0.58^{\mathrm{a}}$ & & & \\
\hline \multirow[t]{2}{*}{$\mathrm{ABbr}$} & $3.13 \pm$ & $138.32 \pm$ & $3.66 \pm$ & $22.9 \pm$ & $1.1 \pm$ & $19.8 \pm$ & $4.18 \pm$ & $3.49 \pm$ & $9.46 \pm$ & $1.49 \pm$ & $0.91 \pm$ & $0.93 \pm$ & $81 \pm 10$ & $16 \pm 9$ & $3 \pm 1$ \\
\hline & $1.69^{\mathrm{ab}}$ & $52.22^{\mathrm{a}}$ & $3.69^{\mathrm{ab}}$ & $8.1^{\mathrm{ab}}$ & $3.0^{\mathrm{ab}}$ & $3.6^{\mathrm{a}}$ & $0.34^{\mathrm{ab}}$ & $0.39^{\mathrm{ab}}$ & $4.45^{\mathrm{ab}}$ & $0.53^{\mathrm{b}}$ & $0.39^{\mathrm{ab}}$ & $0.28^{\mathrm{a}}$ & & & \\
\hline \multirow[t]{2}{*}{ BvBbr } & $1.56 \pm$ & $68.24 \pm$ & $0.64 \pm$ & $8.5 \pm$ & $0.4 \pm$ & $18.0 \pm$ & $4.54 \pm$ & $4.04 \pm$ & $5.85 \pm$ & $1.49 \pm$ & $0.53 \pm$ & $0.77 \pm$ & $82 \pm 10$ & $16 \pm 10$ & $2 \pm 1$ \\
\hline & $0.62^{\mathrm{b}}$ & $25.81^{b}$ & $0.62^{\mathrm{b}}$ & $5.0^{\mathrm{b}}$ & $0.1^{\mathrm{b}}$ & $4.1^{\mathrm{a}}$ & $0.25^{\mathrm{a}}$ & $0.41^{\mathrm{a}}$ & $1.27^{\mathrm{b}}$ & $0.53^{\mathrm{b}}$ & $0.08^{\mathrm{b}}$ & $0.22^{\mathrm{a}}$ & & & \\
\hline \multirow[t]{2}{*}{$\mathrm{BC}$} & $0.93 \pm$ & $20.49 \pm$ & $0.18 \pm$ & $6.0 \pm$ & $0.3 \pm$ & $16.6 \pm$ & $4.60 \pm$ & $4.04 \pm$ & $4.07 \pm$ & $1.12 \pm$ & $0.47 \pm$ & $0.64 \pm$ & $85 \pm 8$ & $13 \pm 7$ & $2 \pm 1$ \\
\hline & $0.77^{\mathrm{b}}$ & $22.76^{b}$ & $0.28^{\mathrm{b}}$ & $1.6^{\mathrm{b}}$ & $0.05^{b}$ & $3.8^{\mathrm{a}}$ & $0.23^{a}$ & $0.15^{\mathrm{a}}$ & $0.79^{b}$ & $0.28^{\mathrm{b}}$ & $0.08^{\mathrm{b}}$ & $0.14^{\mathrm{a}}$ & & & \\
\hline
\end{tabular}

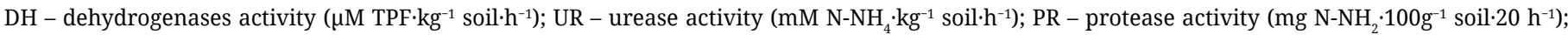
$\mathrm{C}$ and $\mathrm{N}$ content $\left(\mathrm{g} \cdot \mathrm{kg}^{-1}\right)$; $\mathrm{Ca}, \mathrm{K}, \mathrm{Mg}$ and $\mathrm{Na}\left(\mathrm{cmol}(+) \cdot \mathrm{kg}^{-1}\right)$; sand, silt and clay content in \%; small letters in the upper index of the mean values mean significant differences between horizons

nases activity was statistically significantly higher in the surface horizons of Cambic Brunic Arenosols compared to the surface horizons of Albic Brunic Arenosols (Fig. 1). The statistical analyses confirmed the relationship of enzymatic activity with physicochemical properties of soils (Table 4). The activity of all the studied enzymes positively correlated with $\mathrm{C}$ and $\mathrm{N}$ content. The correlation coefficients between UR, PR and DH activity and C content are 0.72, 0.71 and 0.51, respectively. Enzymatic activity was statistically negatively correlated with $\mathrm{pH}$ and sand fraction content.
UR, PR and DH activities were positively correlated with the content of base cations (Table 4). The above mentioned relationships were also confirmed by PCA analysis. Our PCA analysis accounts for $65.36 \%$ of the variability we found in the studied properties (Fig. 2). Factor 1 is related to physicochemical properties and enzymatic activity, while factor 2 is related to soil subtype. The results of the cluster analysis on the basis of Ward's method showed that enzyme activity of various soil horizon differentiated, the surface horizons with a higher UR, PR and DH activity (Fig. 3). 

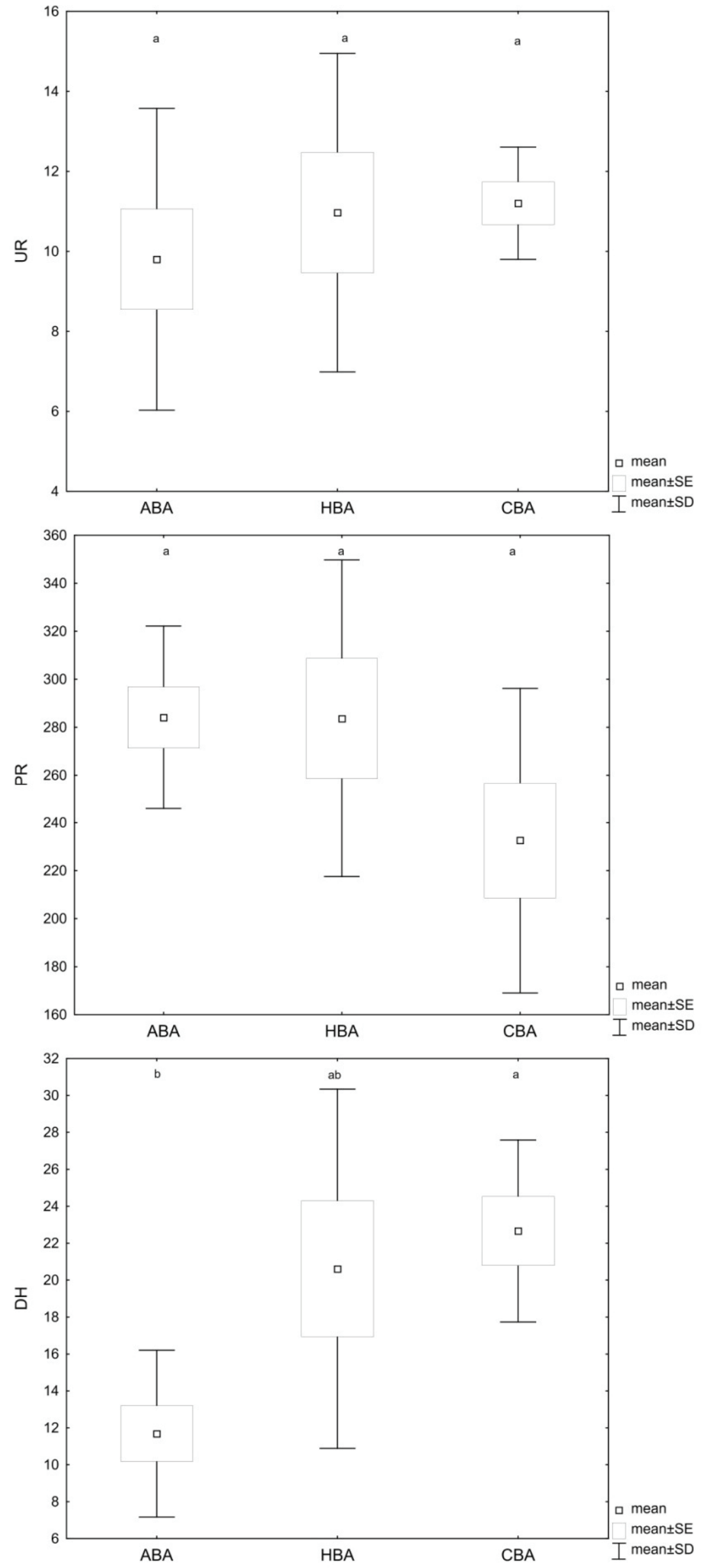

Fig. 1. Enzymatic activity at the surface horizons of Brunic Arenosols various subtypes (DH - dehydrogenases activity; UR - urease activity; PR - protease activity; ABA - Albic Brunic Arenosols; HBA - Haplic Brunic Arenosols; CBA - Cambic Brunic Arenosols) 
Table 4

Correlations between enzyme activity and soil properties in horizon of Brunic Arenosols

\begin{tabular}{|c|c|c|c|c|c|c|c|c|c|c|c|}
\hline & $\mathrm{C}$ & $\mathrm{N}$ & $\mathrm{pH} \mathrm{H}_{2} \mathrm{O}$ & $\mathrm{pH} \mathrm{KCl}$ & $\mathrm{Ca}$ & $\mathrm{K}$ & $\mathrm{Mg}$ & $\mathrm{Na}$ & sand & silt & clay \\
\hline UR & $0.72 *$ & $0.76^{*}$ & $-0.60 *$ & $-0.69^{*}$ & $0.73^{*}$ & $0.73^{*}$ & $0.78^{*}$ & $0.59 *$ & $-0.78^{*}$ & -0.23 & -0.23 \\
\hline$P R$ & $0.71^{*}$ & $0.75^{*}$ & $-0.63^{*}$ & $-0.71^{*}$ & $0.77^{*}$ & $0.75^{*}$ & $0.79 *$ & $0.71^{*}$ & $-0.81^{*}$ & -0.27 & 0.26 \\
\hline $\mathrm{DH}$ & $0.51^{*}$ & $0.59 *$ & $-0.49 *$ & $-0.56^{*}$ & $0.64^{*}$ & $0.59 *$ & $0.62^{*}$ & $0.45^{*}$ & $-0.71^{*}$ & -0.20 & -0.20 \\
\hline
\end{tabular}

$* \mathrm{p}<0.05$
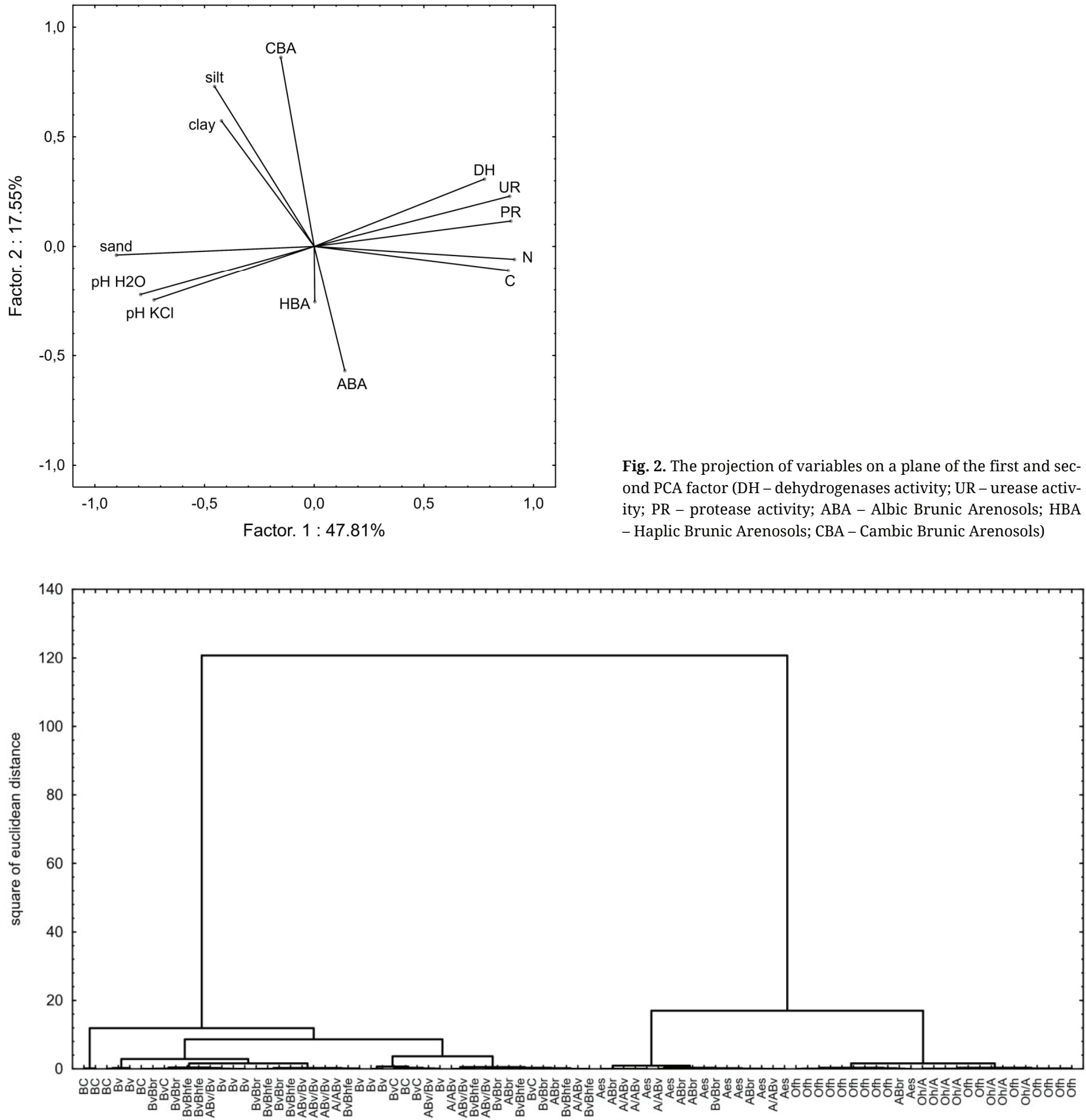

Fig. 2. The projection of variables on a plane of the first and second PCA factor (DH - dehydrogenases activity; UR - urease activity; PR - protease activity; ABA - Albic Brunic Arenosols; HBA - Haplic Brunic Arenosols; CBA - Cambic Brunic Arenosols)

Fig. 3. Cluster analysis on the basis of Ward's method grouping the soil horizon from the Brunic Arenosols; enzymes activity were used in the design of the diagram 


\section{Discussion}

In our study, the activity of the analyzed extracellular enzymes did not differ between subtypes of Brunic Arenosols, while it was strongly related to the organic matter content of each genetic horizon. The highest protease and urease activities were noted in Ofh horizons of Albic Brunic Arenosols and Haplic Brunic Arenosols. The distinctness of the surface horizons in terms of enzymatic activity was confirmed by the cluster analysis on the basis of performed Ward's method. The activity of extracellular enzymes is significantly lower in mineral horizons compared to organic ones. The reduction in the activity of the studied enzymes deeper into the Brunic Arenosols profile is mainly related to the profile distribution of humus and the decreasing with the depth of the soil layers due to the amount of available carbon substrates for microorganisms and enzymes. The activity of extracellular enzymes strongly correlates with the organic carbon content which is in agreement with the results of previous studies (Błońska et al., 2020a and 2021). Soil organic matter is a source of energy and an excellent environment for the growth of microorganisms which simultaneously catalyze most extracellular enzymes (including proteases and urease) (Kotroczó et al., 2014; Stone et al., 2014). Błońska et al. (2020b) confirmed the decreasing trend of soil organic carbon content with increasing soil depth and at the same time reducing the enzymatic activity in both woodland and agricultural soils. The second reason for the patterns found is the strong affinity of extracellular enzymes for organic colloids and their strong sorption (Quiquampoix et al., 1993). In the mineral horizons of Brunic Arenosols, there are few colloids that bind the extracellular enzymes secreted into the soil. Sandy soils typically have lower activity than other soils. Gianfreda et al. (2005) and Błońska et al. (2016) noted a positive correlation between enzymatic activity and clay and silt content and a negative correlation with sand content. The negative correlation of the activity of the determined enzymes with the sand content in the mineral horizons testifies to the great importance of the clay colloids and the silt fraction. In the studied Brunic Arenosols, even a slight admixture of fine fractions creates favorable conditions for an increase in sorption capacity, including the capacity for extracellular enzyme binding by colloids. The consequence of a higher admixture of fine fractions is an improvement of the structural capacity, which increases the activity of microorganisms and enzymes secreted by them (Bach and Hofmockel, 2014; Wang et al., 2015).

In case of dehydrogenases - intracellular enzymes, no such clear differences between organic and mineral horizons were found. In the surface Oh/A horizons of Cambic Brunic Arenosols, the activity of dehydrogenases assumes similar or even higher values than the activity of surface organic horizons (Ofh) of other Brunic Arenosols subtypes. Similar patterns were found for humus-mineral horizons and enrichment horizons. Higher dehydrogenases activities were recorded in the Cambic Brunic Arenosols horizons. It can be assumed that the activity of dehydrogenases better reflects the trophic state of individual Brunic Arenosols subtypes than the studied ex- tracellular enzymes. The Cambic Brunic Arenosols analyzed in this study were associated with the most fertile habitats and mixed or deciduous stands. The amount of mineral and organic colloids determines soil richness and physicochemical properties (Kandeler et al., 1999; Ling et al., 2014). As a rule, soils containing more colloids provide better living conditions for plants and microorganisms, and their microbial activity is higher. Dehydrogenases cannot exist outside living organisms, and as a result they reflect the overall activity of microorganisms living in the soil better. In our study, the analyzed enzymes showed a significant negative relationship with soil $\mathrm{pH}$ and, at the same time, a positive relationship with the content of basic cations. An increase in $\mathrm{pH}$ is a factor that usually stimulates the activity of most soil enzymes, which is associated with a corresponding ionization state of the active center of protein-enzymes, at which the reaction rate increases significantly (Frankenberger and Johanson, 1982, Wolińska and Stępniewska, 2012). In the Brunic Arenosols studied, the effect of $\mathrm{pH}$ is masked by the organic matter content, which is a factor that more significantly affects the activity of the studied soil enzymes.

\section{Conclusions}

Dehydrogenases activity reflects the trophic conditions of Brunic Arenosols better than extracellular enzymes (protease and urease). The highest dehydrogenases activity was recorded in Cambic Brunic Arenosols. Albic Brunic Arenosols were characterized by statistically significantly lower dehydrogenases activity compared to Cambic Brunic Arenosols. For protease and urease activities, no clear differences were noted between Brunic Arenosols subtypes. Extracellular enzymes activity was most strongly associated with organic horizons regardless of Brunic Arenosols subtype. Whatever the enzyme type, there was a decrease in activity deep into the profile which is related to the availability of carbon substrates necessary for enzymatic reactions. Brunic Arenosols subtypes reveal slight differences in granulometric fraction content, and a little increase in the proportion of fine fractions results in a growth in the activity of the tested enzymes. The obtained results indicate the possibility of using enzymatic activity, especially dehydrogenases, in the evaluation of forest soils.

\section{Acknowledgments}

Article was financed by a subvention from the Ministry of Science and Higher Education of the Republic of Poland for the University of Agriculture in Krakow for 2021.

\section{References}

Alef, K., Nannipieri, P., 1995. Enzyme activities. [In:] Methods in applied Soil Microbiology and Biochemistry (Alef K., Nannipieri P., Editors). Academic Press, London, New York, San Francisco, 311-373. 
Allison, S., Wallenstein, M., Bradford, M., 2010. Soil-carbon response to warming dependent on microbial physiology. Nature Geoscience 3, 336-340. https://doi.org/10.1038/ngeo846

Bach, E.M., Hofmockel, K.S., 2014. Soil aggregate isolation metod affects measures of intra-aggregate extracellular enzyme activity. Soil Biology and Biochemistry 69, 54-62.

Baldrian, P., 2014. Distribution of extracellular enzymes in soils: spatial heterogeneity and determining factors AT various scales. Soil Science Society of America Journal 78, 11-18. https://doi.org/10.2136/ sssaj2013.04.0155dgs

Baran, S., Bielińska, J.E., Oleszczuk, P., 2004. Enzymatic activity in an airfield soil polluted with polycyclic aromatic hydrocarbons. Geoderma 118, 221-232. https://doi.org/10.1016/S0016-7061(03)00205-2

Błońska, E., Lasota, J., Gruba, P., 2016. Effect of temperate forest tree species on soil dehydrogenase and urease activities in relation to other properties of soil derived from loess and glaciofluvial sand. Ecological Research 31(5), 655-664.

Błońska, E., Bednarz, B., Kacprzyk, M., Piaszczyk, W., Lasota, J., 2020a. Effect of Scots pine forest management on soil properties and carabid beetle occurrence under post-fire environmental conditions - a case study from Central Europe. Forest Ecosystems 7, 28. https:// doi.org/10.1186/s40663-020-00240-5

Błońska, E., Lasota, J., Rocha Vasconcelos da Silva, G., Vanguelova, E., Ashwood, F., Tibbett, M., Watts, K., Lukac, M., 2020b. Soil organic matter stabilization and carbon-cycling enzyme activity are affected by land management. Annals of Forest Research 63, 71-86.

Błońska, E., Piaszczyk, W., Staszel, K., Lasota, J., 2021. Enzymatic activity of soils and soil organic matter stabilization as an effect of components released from the decomposition of litter. Applied Soil Ecology 157, 103723. https://doi.org/10.1016/j.apsoil.2020.103723

Burns, R.G., Dick, R.P., 2002. Enzymes in the environment: activity, ecology and applications. Mercel Dekker, New York, 1-640.

Cusack, D.F., Silver, W.L., Torn, M.S., Burton, S.D., Firestone, M.K., 2011. Changes in microbial community characteristics and soil organic matter with nitrogen additions in two tropical forests. Ecology 92, 621-632. https://doi.org/10.1890/10-0459.1

Everrit, B., 1980. Cluster analysis. Reviews of current research. Social Science Research Council, Halstead Press, New York, pp. 11.

Frankenberger, W.T., Johanson, J.B., 1982. Effect of pH on enzyme stability in soil. Soil Biology and Biochemistry 14, 433-437.

Friedlová, M., 2010. The influence of heavy metals on soil biological and chemical properties. Soil Water Research 5, 21-27. https://doi. org/10.17221/11/2009-SWR

Gianfreda, L., Rao, A.M., Piotrowska, A., Palumbo, G., Colombo, C., 2005. Soil enzyme activities as affected by anthropogenic alterations: intensive agricultural practices and organic pollution. Science of the Total Environment 341, 265-79.

Haziev, F.H., 1976. Fermentativnaâ aktivnost počv. Izd. Nauka, Moskwa.

Hernández, D.L., Hobbie, S.E., 2010. The effects of substrate composition quantity, and diversity on microbial activity. Plant and Soil 335, 397 411. https://doi.org/10.1007/s11104-010-0428-9

Kandeler, E., Stemmer, M, Klimanek, E.M., 1999. Response of soil microbial biomass, urease and xylanase within particle size fraction to longterm soil management. Soil Biology and Biochemistry 31, 261-273.

Klasyfikacja Gleb Leśnych Polski. 2000. CILP Warszawa

Kotroczó, Z., Veres, Z., Fekete, J., Krakomperger, Z., Tóth, J.A., Lajtha, K., Tóthmérész, B., 2014. Soil enzyme activity in response to long-term organic matter manipulation. Soil Biology and Biochemistry 70: 237-243. https://doi.10.1016/j.soilbio.2013.12.028

Kumar, S., Chaudhuri, S., Maiti S.K., 2013. Soil dehydrogenase enzymes activity in natural and mine soil-a review. Middle East Journal Science Research 13, 898-906. https://doi.10.5829/idosi.mejsr.2013.13.7.2801

Lasota J, Błońska E., 2013. Forest Site Science in the Polish Lowlands and Highlands; Scientific Papers; University of Agriculture in Krakow, Kraków, Poland.

Lasota, J., Błońska, E., 2018. Polycyclic aromatic hydrocarbons content in contaminated forest soils with different humus type. Water Air and Soil Pollution 229, 204. https://doi.org/10.1007/s11270-018-3857-3

Ling, N., Sun, Y., Ma, J., Guo, J., Zhu, P., Peng, C., Yu, G., Rau, W., Guo, S., Shen, Q., 2014. Response of the bacterial diversity and soil enzyme activity in particle-size fraction of Mollisol after different fertilization in a long-term experiment. Biology Fertility of Soil 50, 901-911.

Lipińska, A., Kucharski, J., Wyszkowska, J., 2013. Urease activity in soil contamined with polycyclic aromatic hydrocarbons. Polish Journal of Environmental Studies 22, 1393-1400.

Margesin, R., Zimmerbauer, A., Schinner, F., 2000. Monitoring of bioremediation by soil biological activities. Chemosphere 40, 339-346. https://doi.org/10.1016/S0045-6535(99)00218-0

Sardans, J., Peńuelas, J., Estiarte, M., 2008. Changes in soil enzymes related to $\mathrm{C}$ and $\mathrm{N}$ cycle and in soil $\mathrm{C}$ and $\mathrm{N}$ content under prolonged warming and drought in a Mediterranean shrubland. Applied Soil Ecology 39, 223-235. https://doi.org/10.1016/j.apsoil.2007.12.011

Schimel, J.P., Weintraub, M., 2003. The implications of exoenzyme activity on microbial carbon and nitrogen limitation in soil: a theoretical model. Soil Biology and Biochemistry 35, 549-563. https://doi. org/10.1016/S0038-0717(03)00015-4

Sinsabaugh, R.L., Lauber, C.L., Weintraub, M.N., Ahmed, B., Allison, S.D., Crenshaw, C., Contosta, A.R., Causack, D., Frey, S., Gallo, M.E., Gartner, T.B., Hobbie, S.E., Holland, K., Keeler, B.L., Powers, J.S., Stursova, M., Takacs-Vesbach, C., Wallenstein, M.D., Zak, D.R., Zeglin, L.H., 2008. Stoichiometry of soil enzyme activity at global scale. Ecology Letters 11, 1252-1264. https://doi.org/10.1111/j.1461-0248.2008.01245.x

StatSoft Inc., 2012. STATISTICA (version 13.0). Computer software.

Stone, M.M., DeForest, J.L., Plante, A.F., 2014. Changes in extracellular enzyme activity and microbial community structure with soil depth at the Luquillo Critical Zone Observatory. Soil Biology and Biochemistry 75, 237-247. https://doi.org/ 10.1016/j.soilbio.2014.04.017

Tabatabai, M.A., Bremner, J.M., 1972. Assay of urease activity in soils. Soil Biology and Biochemistry, 4, 479-487.

Wang, R., Dorodnikov, M., Yang, S., Zhang, Y., Filley, T.R., Turco, R.F., Zhang, Y., Xu, Z., Li, H., Jiang, Y., 2015. Responses of enzymatic activities within soil aggregates to 9-year nitrogen and water addition in a semi-arid grassland. Soil Biology and Biochemistry 81, 159-167.

Wolińska, A., Stępniewska, Z., 2012. Dehydrogenase activity in the soil environment. In: Canuto RA (eds) Dehydrogenases. In-Tech.

Quiquampoix, H., Staunton, S., Baron, M.H., Ratkliffe, R.G., 1993. Interpretation of the $\mathrm{pH}$ dependence of protein adsorption on clay mineral surfaces and its relevance to the understanding of extracellular enzyme activity in soil. Colloids and Surfaces A: Physicochemical and Engineering Aspects 75, 85-93.

Zhan, X., Wu, W., Zhou, L., Liang, J., Jiang, T., 2010. Interactive effect of dissolved organic matter and phenanthrene on soil enzymatic activities. Journal of Environmental Science 22, 607-614. https://doi. org/10.1016/S1001-0742(09)60139-X 

Stan aktywności enzymatycznej gleb w zależności od wybranych właściwości
chemicznych gleb rdzawych

\section{Streszczenie}

Gleby rdzawe są jednym z najczęściej spotykanych typów gleb w lasach terenów niżowych. Celem badań było określenie aktywności enzymatycznej leśnych gleb rdzawych zróżnicowanych troficznie. W pracy podjęto próbę określenia relacji pomiędzy aktywnością enzymatyczną a wybranymi właściwościami chemicznymi gleb rdzawych. Przedstawiono jak aktywność dehydrogenaz, ureazy i proteazy zmienia się w głąb profilu gleb rdzawych. Badania przeprowadzono w środkowej części Polski, na terenie Nadleśnictwa Przedbórz. Do badań wytypowano 23 powierzchnie badawcze. Badania dotyczyły gleb rdzawych bielicowych (9 powierzchni badawczych), gleb rdzawych właściwych (7 powierzchni badawczych) oraz gleb rdzawych brunatnych (7 powierzchni badawczych). Na każdej powierzchni badawczej przeprowadzono szczegółowy opis profilu glebowego oraz pobrano próbki z każdego poziomu genetycznego w celu wykonania podstawowych oznaczeń właściwości gleby i aktywności enzymatycznej. Przeprowadzone analizy potwierdziły zależność aktywności enzymatycznej z zawartością C, N, pH oraz uziarnieniem badanych gleb. Bez względu na rodzaj enzymu, zanotowano spadek aktywności w głąb profilu co wiąże się z dostępnością substratów węglowych niezbędnych do reakcji enzymatycznych. Spośród badanych enzymów, aktywność dehydrogenaz lepiej odzwierciedlała troficzne warunki gleb rdzawych. Najwyższą aktywność dehydrogenaz zanotowano w glebach rdzawych brunatnych. W przypadku aktywności proteazy i ureazy nie zanotowano wyraźnych różnic pomiędzy podtypami gleb rdzawych. Aktywność enzymów zewnątrzkomórkowych najsilniej była związana z poziomami organicznymi bez względu na podtyp gleb. 